\title{
Fe-pillared clay mineral-based formulations of imazaquin for reduced leaching in soil
}

\author{
T. Undabeytia M.C. Galán-Jiménez , E. Gómez-Pantoja , J. Vázquez ', B. Casal , F. Bergaya ，E. Morillo
}

\begin{abstract}
Slow release formulations of the herbicide imazaquin (2-(4-isopropyl-4-methyl-5-oxo-4,5-dihydro-1Himidazol-2-yl)quinoline-3-carboxylic acid) were prepared by its adsorption on Fe-pillared clay minerals (Fe PILCs). Fe PILCs were synthesized by the reaction of $\mathrm{Na}^{+}$-montmorillonite (SWy-2) with base-hydrolyzed solutions of $\mathrm{Fe}$ and $\mathrm{Al}$. The $\mathrm{Fe} /(\mathrm{Fe}+\mathrm{Al})$ ratios used were $0,0.05,0.15$ and 0.50 . Fe PILCs showed basal spacing values of 5.2 and $1.8 \mathrm{~nm}$ which were due to iron clusters between delaminated clay layers, and intercalated aluminum polyoxocations, respectively. As iron content increased, the pillaring process yielded PILC with lower microporosity and larger mesoporosity. The affinity of imazaquin on Fe PILCs was very high relative to Al PILC, as revealed in its higher herbicide adsorption values and lower desorption percents. Competitive adsorption of anions such as sulfate, phosphate and chloride provided evidence of formation of inner sphere complexes of imazaquin on Fe PILCs. Slow release formulations were prepared by enhanced adsorption of the herbicide from imazaquin-cyclodextrin (CD) complexes in solution. CDs were able to enhance up to 8.5 -fold the solubility of imazaquin, by the formation of inclusion complexes where the quinolinic moiety of the herbicide was partially trapped within the $\mathrm{CD}$ cavity. Release of the herbicide in sandy soil was about $1 / 2$-fold lower from Fe PILC formulations relative to the commercial formulation.
\end{abstract}

\section{Introduction}

Herbicides are applied to impede the growth of weeds and improve the yield of crops. However, only a part of the applied amount reaches its target whereas the rest remains either attached to the soil colloids or undergoes degradation and transfer processes such as migration of the herbicide to surface and groundwater, which has been reported to be one of the main sources of polluted waters (Finizio et al., 2011; Metcalfe et al., 2011). To minimize this effect, research has focused in the last decades on the development of slow release formulations (SRFs) of herbicides that permit to decrease the losses of the used amounts but to achieve good bioactivity, thus providing safer environmental formulations (Fernández-Urrusono et al., 2000; Sopeña et al., 2005; Undabeytia et al., 2000, 2003, 2010).

Clay minerals have been studied as good candidates for SRF because of their good adsorbent properties in addition to their abundance and low-cost. Most of the studies were performed on montmorillonite (Mt) whose surface was modified previously from hydrophilic to hydrophobic by pre-adsorbing organic cations, which were further used for enhanced adsorption of the active ingredient. In general, high adsorption is usually correlated with slow release properties (Mishael et al., 2003). Recently, hydrotalcites were used based on the same principle, but using organic anions (Zhenlan et al., 2009). Other clay mineral-based approaches were trapping of the herbicide by coagulation of delaminated clay mineral layers (Nennemann et al., 2001a), adsorption after previous thermal treatment (Bojemueller et al, 2001), bentonite polymer gels ( $\mathrm{Li}$ et al., 2009), and sepiolite gels (Maqueda et al., 2008, 2009).

Pillared clay minerals (PILCs) were proved very effective in the adsorption of herbicides and organic contaminants due to geometrical compatibility between the structural pores and molecular dimensions of the chemicals, in addition to their specific interactions with the pillars and layers of the clay mineral (Cheknane et al., 2010). Adsorption capacity of PILC was used for the preparation of SRF of herbicides (Gerstl et al., 1998; Nennemann et al., 2001b).

Imazaquin (IMZQ) is a selective imidazolinone herbicide used for broad-spectrum weed control in legume crops (Ahrens, 1994). IMZQ has an acidic carboxyl and a basic quinoline functional group with pKa values of 3.8, and 2.0, respectively (Regitano et al., 2005). Therefore, it exists as an anion at typical soil $\mathrm{pH}$ values, increasing its risk for leaching down the soil profile. A PILC formulation was designed to reduce its leaching in soil (Polubesova et al., 2002). In the current work, SRFs of the herbicide imazaquin were designed based on PILC prepared from hydrolyzed iron solutions instead. Imidazolinone herbicides are known to form complexes with transition metals (Erre et al., 1998). Imazaquin adsorption on soils with different physicochemical properties was greater on the soil containing higher amorphous iron oxide content 
(Undabeytia et al., 2004). This pointed to the formation of stronger complexes with iron over other elements as aluminum, and hence, enhanced imazaquin adsorption and stronger retention on Fe PILC. The validity of this approach for the preparation of SRF was examined in the current paper.

In general, the active ingredient loading on clay-based formulations is limited by the herbicide solubility, which prevents further adsorption. Cyclodextrins (CDs) are cyclic oligosaccharides produced by the enzymatic breakdown of starch by bacteria. These molecules have a toroidal shape, with a hydrophobic interior cavity and hydrophilic faces (Szejtli, 1998). The ability of these molecules to form inclusion complexes with non-polar molecules has been exploited in the pharmaceutical industry as a solubility enhancement agent (Bikiaris, 2011). Environmental applications for subsurface soil remediation of organics have started to be described based on the very poor $\mathrm{CD}$ adsorption on soil colloids (Fenyvesi et al., 2011; Villaverde et al., 2005). Therefore, the active ingredient content of the PILC formulations can be increased by performing adsorption of the herbicide in solution from $\mathrm{CD}$ inclusion complexes. The herbicide will be solubilized and adsorbed on the clay mineral whereas the $\mathrm{CD}$ will remain mostly in solution.

The objectives of this work were: (i) to prepare Fe PILCs as adsorbents for the preparation of SRF; (ii) to study the formation of inclusion complexes of IMZQ with CD; (iii) to prepare slow release formulations from CD-IMZQ solutions; and finally (iv) to test these formulations for slow release.

\section{Materials and methods}

\subsection{Materials}

Wyoming $\mathrm{Na}^{+}-\mathrm{Mt}$ (SWy-2) was obtained from the Source Clays Repository of The Clay Minerals Society (Columbia, MO) (cation exchange capacity $0.8 \mathrm{mmol} / \mathrm{g})$. Al (NO) $)_{3} \cdot 9 \mathrm{H}_{2} \mathrm{O}, \mathrm{FeCl}_{3} \cdot 6 \mathrm{H}_{2} \mathrm{O}, \mathrm{NaCl}, \mathrm{Na}_{2} \mathrm{SO}_{4}$, $\mathrm{Na}_{3} \mathrm{PO}_{4}, \mathrm{H}_{3} \mathrm{PO}_{4}$ and $\mathrm{NaOH}$ were purchased from Sigma-Aldrich (Sigma
Chemical Co., St. Louis, MO). HPLC grade-acetonitrile was obtained from Teknokroma S.A. (Barcelona, Spain). Imazaquin (IMZQ 97\% purity) was supplied by Sigma-Aldrich and its commercial formulation (Scepter, 180 g a.i. $\mathrm{L}^{-1}$ ) by Agan Makteshim (Lérida, Spain). Cyclodextrins (CDs) were purchased from Cyclolab (Budapest, Hungary). CDs employed were: $\alpha-C D, \beta-C D$, hydroxypropyl- $\beta-C D(H P \beta)$, and randomly methylated- $\beta-C D$ (RAME $\beta$ ). Fig. 1 shows the structural formulas of IMZQ and $\mathrm{CD}$.

The upper part $(0-20 \mathrm{~cm})$ of sandy soil classified as Typic Xeropsamment was collected, and passed through a $2 \mathrm{~mm}$ sieve before use. This soil has a pH of 8.9 and $0.79 \%$ of organic matter (more detailed physicochemical properties are given in Undabeytia et al., 2012).

\subsection{Preparation of pillared clay minerals}

Aluminum nitrate and iron chloride solutions in several $\mathrm{Fe} /(\mathrm{Al}+\mathrm{Fe})$ molar ratios $(0,0.05,0.15,0.5)$ were hydrolyzed by titration with $0.4 \mathrm{M}$ $\mathrm{NaOH}$ under nitrogen atmosphere. The $\mathrm{Al} / \mathrm{OH}$ molar ratio was 2.0. These pillaring solutions were aged for 7 days. Then, $10 \mathrm{~g}$ of clay mineral was dispersed in $250 \mathrm{~mL}$ water, and the pillaring solutions in a ratio of $10 \mathrm{mmol}(\mathrm{Fe}+\mathrm{Al}) / \mathrm{g}$ clay mineral were added slowly with a peristaltic pump under nitrogen atmosphere. The final clay mineral content was $1 \%$ (w:w). The dispersions were under shaking for $24 \mathrm{~h}$, followed by centrifuging, removal of chloride by dialysis, and dry-freezing. Finally, the powder clay minerals were heated for $3 \mathrm{~h}$ at $300{ }^{\circ} \mathrm{C}$ under nitrogen atmosphere.

A nomenclature was used for the PILCs where the first letters, $\mathrm{Al}$ or Fe, respectively indicated the absence or presence of iron in the pillaring solutions, and the following numbers indicated the used $\mathrm{Fe} /(\mathrm{Al}+\mathrm{Fe})$ ratio.

\subsection{Characterization of PILC}

The chemical composition of the PILC was determined by X-ray fluorescence (PANalytical Model Axios).<smiles>CC(=O)Oc1nc2cc[c]cc2cc1C(=O)O</smiles>

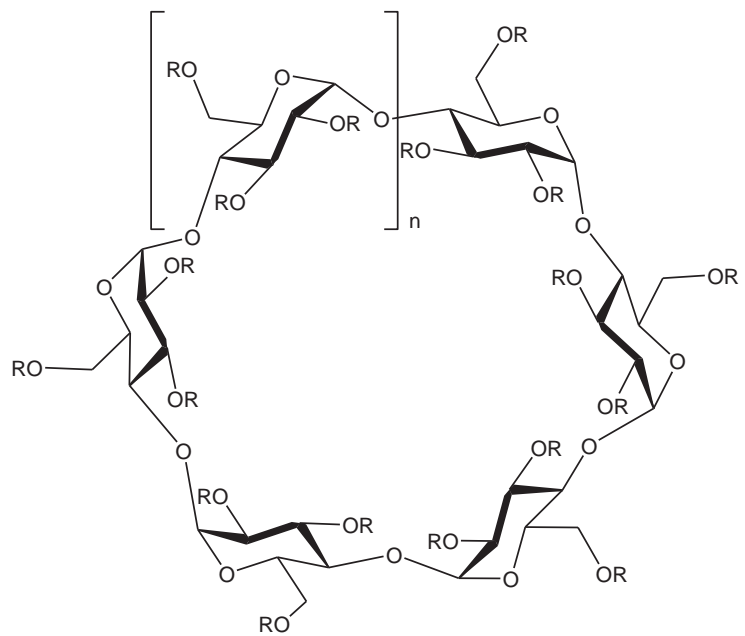

$\alpha-C D, n=1, R=H$

$\beta-C D, n=2, R=H$

$\mathrm{HP}-\beta, n=2, \mathrm{R}=\mathrm{H}$ or $\mathrm{CH}_{2}-\mathrm{CHOH}-\mathrm{CH}_{3}$

RAME $\beta, n=2, \mathrm{R}=\mathrm{H}$ or $\mathrm{CH}_{3}$

Fig. 1. Structural formulas of the herbicide imazaquin and cyclodextrins. 
X-ray diffraction of the clay mineral samples was performed on a Philips X'Pert diffractometer (model Anton Paar HTK) with $\mathrm{Cu} \mathrm{K \alpha}$, $26 \mathrm{~mA}$ and $36 \mathrm{kV}$, counting time of $10 \mathrm{~s} /$ step collected from 1 to $25^{\circ}(2 \theta)$.

Surface area values were determined by using the BET method. The adsorption of $\mathrm{N}_{2}$ was measured with a multi-station high speed gas sorption analyzer (Quantachrome Instruments NOVA 4200). The samples were outgassed by heating at $200{ }^{\circ} \mathrm{C}$ for $2 \mathrm{~h}$.

Fourier transform infrared (FTIR) spectra of the Fe-0.5 PILC were recorded in $\mathrm{KBr}$ pellets (2 wt.\% sample) using a JASCO spectrometer (model FT/IR 6300) with a DTGS detector, in the range of 4000$700 \mathrm{~cm}^{-1}$. Resolution was of $2 \mathrm{~cm}^{-1} .300$ scans were accumulated for improving the signal to noise ratio in the spectra.

\subsection{Adsorption-desorption studies}

IMZQ adsorption experiments were performed in duplicate by mixing $24 \mathrm{mg}$ of the PILCs with $15 \mathrm{~mL}$ of herbicide solutions ranging up to $160 \mu \mathrm{M}$. Preliminary kinetic studies indicated that adsorption reached equilibrium after $24 \mathrm{~h}$; thus, the dispersions were shaken for $24 \mathrm{~h}$ at $20^{\circ} \mathrm{C}$. Subsequently, the dispersions were centrifuged and the concentration of herbicide in the supernatants was analyzed. Desorption experiments were also performed for certain concentrations (16, 64 and $160 \mu \mathrm{M}$ ) by replacing the whole supernatant of the adsorption experiments with water, re-equilibrating for $24 \mathrm{~h}$, centrifuging and further analyzing of the herbicide in the supernatant.

Adsorption of IMZQ on PILCs was also studied in the presence of $\mathrm{NaCl}, \mathrm{Na}_{2} \mathrm{SO}_{4}$ and $\mathrm{Na}_{3} \mathrm{PO}_{4}$ electrolytes. The added amount of both herbicide and electrolyte anion was $160 \mu \mathrm{eq} / \mathrm{L}$. Clay mineral concentration was also $1.6 \mathrm{~g} / \mathrm{L}$.

IMZQ-CD complexes were prepared from solutions of $100 \mathrm{mM} \mathrm{CD}$ containing dissolved amounts of IMZQ as determined previously from the solubility diagrams (1.61 and $1.29 \mathrm{mM}$ for HP $\beta$ and RAME $\beta$, respectively), by successive dilutions. Fe-0.5 PILC was treated with the IMZQ-CD solutions at $1.6 \mathrm{~g} / \mathrm{L}$, and the adsorbed herbicide was determined as previously indicated. The amount of $\mathrm{CD}$ adsorbed was determined by analysis of the supernatant as described in Takeuchi and Miwa (1999).

FTIR spectra of the herbicide before and after adsorption on Fe-0.5 PILC were also recorded.

\subsection{Imazaquin solubility studies in the aqueous phase in the presence of different $C D s$}

Solubility studies were carried out according to the method reported by Higuchi and Connors (1965). IMZQ (10 mg) was added in excess of its solubility at $25{ }^{\circ} \mathrm{C}(60 \mathrm{mg} / \mathrm{L})$ to aqueous solutions $(10 \mathrm{~mL})$ containing various concentrations of one of the CDs. The range was from 0 to $16 \mathrm{mM}$ for $\beta-C D$ and from 0 to $100 \mathrm{mM}$ for $\alpha-C D, H P \beta$ and RAME $\beta$. The experiments were carried out in triplicate. Flasks containing the dispersions were sealed and shaken for 1 week. This reaction time was chosen after preliminary kinetic studies (data not shown). Dispersions were then filtered using a syringe through a $0.22-\mu \mathrm{m}$ Millipore cellulose glass fiber membrane filter, and the concentration of IMZQ in the filtrate was determined by HPLC (Shimadzu Model 10A) equipped with a PDA detector as described in Undabeytia et al. (2008).

The apparent stability constant $\mathrm{Kc}$ was calculated from the straight line obtained in the phase solubility diagram, following the equation proposed by Higuchi and Connors (1965):

$\mathrm{Kc}=$ Slope $/ \mathrm{S}_{0}(1-$ Slope $)$

where $S_{0}$ is the IMZQ equilibrium concentration in aqueous solution in the absence of $\mathrm{CD}$, and Slope is the slope of the phase solubility diagram. Solubility efficiency (Se) was also obtained from the solubility diagrams, which is defined as the increment in the apparent solubility of IMZQ at a fixed CD concentration with respect to its solubility in the absence of $C D$.

The inclusion complex of the herbicide with RAMEß was characterized by ${ }^{1} \mathrm{H}-\mathrm{NMR}$. The experiments were run at $25{ }^{\circ} \mathrm{C}$ using a Bruker AMX 500 spectrometer. The concentrations employed were $100 \mathrm{mM}$ for CD and $1.28 \mathrm{mM}$ for IMZQ.

\subsection{Preparation of imazaquin formulations}

The formulations were prepared by adsorption of IMZQ-CD complexes on Fe-0.5 PILC at $1.6 \mathrm{~g} / \mathrm{L}$. The used CDs were HP- $\beta$ and RAMEß. The used concentrations were $100 \mathrm{mM}$ for both CDs, and the amount of IMZQ dissolved in the CD solutions was $1.61 \mathrm{mM}$ for $\mathrm{HP} \beta$ and $1.29 \mathrm{mM}$ for RAMEß.

The dispersions were shaken for $24 \mathrm{~h}$ at $20{ }^{\circ} \mathrm{C}$. Then, the herbicide was analyzed in the removed supernatant, whereas the pellets were dry-frozen yielding the PILC formulations. They were denoted as Fe-0.5 PILC-HPß and Fe-0.5 PILC-RAMEß.

\subsection{Release of herbicide}

The release of the herbicide from Fe-0.5PILC and commercial formulation was conducted by using Büchner funnels. In this procedure $98.9 \mathrm{~g}$ of the sandy soil was added to a Büchner funnel $(9.5 \mathrm{~cm}$ internal diameter) equipped with a paper filter on the bottom. The soil layer was homogenized to a $0.5 \mathrm{~cm}$ height. The soil surface was uniformly sprayed with the different herbicide formulations at a rate of $140 \mathrm{~kg}$ of active ingredients per ha. The soil layer in each funnel was irrigated 14 times with $15 \mathrm{~mL}$, each washing corresponding to $2.12 \mathrm{~mm}$ rain at $20 \mathrm{~min}$ intervals. The volume eluted after each irrigation was collected, and the concentration of herbicide in the eluent was determined.

\section{Results and discussion}

\subsection{PILC characterization}

Table 1 shows the clay mineral elemental composition obtained from the raw clay and after pillaring with $\mathrm{Al}$ and Al-Fe oligomers. Intercalation of these oligomers was successful as noted in the increase in $\mathrm{Al}$ content relative to the initial clay mineral and also in the increase in Fe which paralleled the $\mathrm{Fe} /(\mathrm{Al}+\mathrm{Fe})$ ratio used in the pillaring process.

There is also a decrease in the octahedral $\mathrm{Mg}$ content in the pillared clay minerals due to the attack of protons from the oligomeric cations, which are decomposed after heating in oxide pillars with the subsequent proton release (Bradley and Kydd, 1993). This Mg release yielded hydroxyl acid sites. However, these acid sites are not responsible of the strong Brönsted acidity reported in these types of materials, which is rather attributed to $\mathrm{Al}$ (or Al-Fe) pillars (Zubkov et al., 1994) as a consequence of the greater dissociation of pillars by hydrating water molecules (Schutz et al., 1987).

Table 1

Chemical analysis of the raw clay mineral and PILCs expressed as oxide percentage.

\begin{tabular}{lccccc}
\hline & SWy-2 & Al-PILC & Fe-0.05-PILC & Fe-0.15-PILC & Fe-0.5-PILC \\
\hline $\mathrm{SiO}_{2}$ & 60.08 & 56.94 & 47.95 & 45.49 & 34.36 \\
$\mathrm{Al}_{2} \mathrm{O}_{3}$ & 17.89 & 21.28 & 24.94 & 23.00 & 16.14 \\
$\mathrm{Fe}_{2} \mathrm{O}_{3}$ & 3.84 & 1.00 & 7.39 & 15.00 & 31.18 \\
$\mathrm{~K}_{2} \mathrm{O}$ & 0.46 & 0.21 & 0.34 & 0.35 & 0.27 \\
$\mathrm{MgO}$ & 2.48 & 2.56 & 1.79 & 1.61 & 1.10 \\
$\mathrm{CaO}$ & 1.22 & 0.06 & 0.06 & 0.07 & 0.07 \\
$\mathrm{Na}_{2} \mathrm{O}$ & 1.39 & 0.14 & 0.19 & 0.18 & 0.12 \\
\hline
\end{tabular}




\subsection{Porosity}

The X-ray diffractograms corresponding to the PILC by intercalation of $\mathrm{Al}$ and Fe oligomers are shown in Fig. 2. The Al PILC showed basal spacing at $1.8 \mathrm{~nm}$, indicating a $0.9 \mathrm{~nm}$ interlayer space in good agreement with the size of the Keggin cation. In contrast, Al-Fe PILC showed an additional peak at $5.2 \mathrm{~nm}$, which remained constant when increasing $\mathrm{Fe} /(\mathrm{Fe}+\mathrm{Al})$ ratio. This peak at low angle was of lower intensity compared to that at $1.8 \mathrm{~nm}$ for an $\mathrm{Fe} /(\mathrm{Al}+\mathrm{Fe})$ ratio of 0.05 . However, the contrary tendency was observed at larger ratios, a noticeable decrease in the intensity of the peak at $1.8 \mathrm{~nm}$ which was shifted to higher angles for an $\mathrm{Fe} /(\mathrm{Al}+\mathrm{Fe})$ ratio of 0.5 . This tendency was already observed by Mandalia et al. (1998). These authors obtained basal spacing values as high as $7.2 \mathrm{~nm}$ for an $\mathrm{Fe} /(\mathrm{Al}+\mathrm{Fe})$ ratio of 0.5 . The different observed basal spacing values at low angles can be due to the different $(\mathrm{Fe}+\mathrm{Al}) / \mathrm{OH}$ ratios used in the formation of the $\mathrm{Fe}$ and $\mathrm{Al}$ oligomers, since the pillaring process is strongly dependent on experimental conditions such as temperature and $\mathrm{pH}$, and also dependent on the nature of the exchangeable cation and especially on the metal/base ratio used.

The high basal spacing obtained in the current study differed with the vast majority of previous studies performed with Fe-based PILCs (Bandosz and Cheng, 1997; Cañizares et al., 1999; Heylen and Vansant, 1997) which showed the largest basal spacing of about $2.5 \mathrm{~nm}$. This can be due to the fact that the starting materials were clay minerals with higher CEC than SWy-2. Al polyoxocations are more effective in neutralizing negative charge because of their more planar shapes than those of Fe that have a more spherical shape (Oades, 1984). Consequently, the lower the clay mineral layer charge, the lower the Al-oligomer competition and the larger the $\mathrm{Fe}$ polyoxocation intercalation. Clinard et al. (2003) observed by transmission electron microscopy that Al-Fe PILCs are composed by particles separated from each other by regular mesopores, which contained compact aggregates of Fe oxide nodules. The spheroid clusters formed by condensation of these Fe nodules had an approximate diameter of $3.8 \mathrm{~nm}$. This value correlated quite well with an interlayer space of approximately $4.2 \mathrm{~nm}$ corresponding to the basal spacing of $5.2 \mathrm{~nm}$, in the current study.

The diffraction observed at $1.8 \mathrm{~nm}$ was the only peak for samples prepared in the absence of iron; therefore, this peak was due to the formation of Al pillars as usually described in Al-PILC (Bergaya et al., 2006). The intensity decrease observed for this diffraction peak to $1.4 \mathrm{~nm}$ in Fe-0.5 PILC indicated the presence of smaller Al oligomers. The XRD data agreed with previous Mössbauer results that indicated no Al substitution in the Fe pillars and that $\mathrm{Al}$ and Fe formed separate pillars or phases in the interlayer space (Aouad et al., 2010).

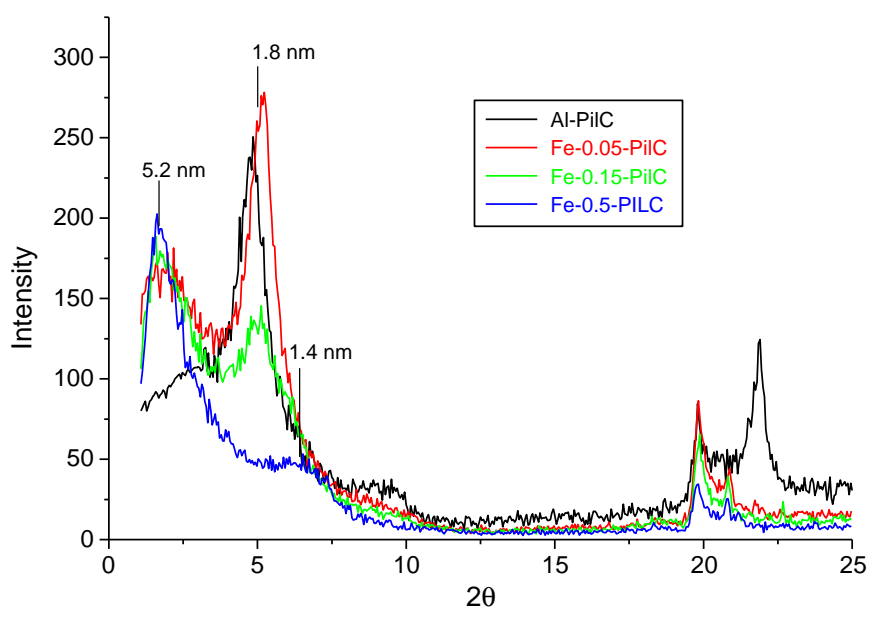

Fig. 2. X-ray diffraction of PILCs.
The pillaring process increased considerably the total surface area (Table 2 ) compared to the $S_{\mathrm{BET}}$ of the raw clay mineral $\left(32 \mathrm{~m}^{2} \mathrm{~g}^{-1}\right)$. The $\mathrm{S}_{\mathrm{BET}}$ decreased slightly (about $20 \%$ reduction) with increased $\mathrm{Fe}$ content. However, the micropore area decreased by about $80 \%$ from Al PILC to Fe-0.5-PILC. The larger decrease for the micropore area vs. the total surface area indicated that most of the new surface area created in the pillaring process with Fe species corresponded to mesoand macropores. In general, the materials produced from intercalation of iron oxyhydroxides create smaller micropore volumes and surface areas compared to Al PILC (Bakas et al., 1994; Mishra et al., 1996; Pinnavaia et al., 1983). This was usually attributed to iron species adsorbed on the external surface of the smectite leading to spatial arrangement with pore formation of different sizes in the micro- and mesopore region (Bandosz and Cheng, 1997; Marco-Brown et al., 2012). The mesopores resulted from interparticle spaces generated by three-dimensional coaggregation of iron polyoxocations on the clay mineral surface forming delaminated structures, whereas micropores arose from intercalation of smaller hydrolyzed iron oxides and from microporous interstices existing among the iron aggregates and clay mineral layers (Yuan et al., 2008).

\subsection{Adsorption isotherms}

IMZQ did not adsorb on the raw Mt (SWy-2) used in the pillaring processes due to electrostatic repulsion at the equilibrium $\mathrm{pH}$ between the negatively charged molecules of the herbicide and the negatively charged clay mineral layers. However, the herbicide adsorbed on PILC, with increased adsorption as the iron content increased (Fig. 3). This agreed with previous studies that reported enhanced IMZQ adsorption by $\mathrm{Al}$ and $\mathrm{Fe}$ oxyhydroxides in soils with low organic matter content (Gennari et al., 1998; Regitano et al., 1997). Undabeytia et al. (2004) studied IMZQ adsorption in soils with different physicochemical properties, and observed that the highest adsorption occurred on loam silt soil due to its high content of amorphous iron oxides. This high affinity of the IMZQ herbicide to iron oxides would explain values for maximal adsorption up to four-fold larger than that on Al PILC.

Adsorption on Fe PILC was related to the iron content as well as to the porosity of the samples. IMZQ adsorption increased as the mesoand macropore surface increased. Therefore, IMZQ interaction with the pillars in the interlayer spaces is greatly facilitated. However, the greater IMZQ retention on Fe PILCs over Al PILC was probably related to a stronger adsorption mechanism. Al PILC showed higher external surface area value than Fe-0.05 PILC, but its IMZQ adsorption was lower. Polubesova et al. (2002) suggested that IMZQ adsorption on Al PILC was occurring through electrostatic interactions of the anionic herbicide molecules with positively charged sites of pillars that are attributed to Lewis acidity, in addition to hydrogen bonding of Brönsted acid sites with the carboxylate moiety, nitrogen and oxygen atoms of IMZQ. Both mechanisms provide less tight binding than inner-sphere complexation, facilitating IMZQ desorption. Desorption of IMZQ was performed by replacing the complete supernatant by distilled water (Table 3). The desorption percents were extremely high with Al PILC and independent of the initial concentration, but were largely reduced when using Fe PILC, the largest the increase in

Table 2

Surface characterization of PILCs.

\begin{tabular}{llcc}
\hline Sample & $\begin{array}{l}\mathrm{S}_{\mathrm{BET}} \\
\left(\mathrm{m}^{2} \mathrm{~g}^{-1}\right)\end{array}$ & $\begin{array}{l}\text { External surface } \\
\text { area }\left(\mathrm{m}^{2} \mathrm{~g}^{-1}\right)\end{array}$ & $\begin{array}{l}\text { Micropore area } \\
\left(\mathrm{m}^{2} \mathrm{~g}^{-1}\right)\end{array}$ \\
\hline Al PILC & 213 & 34 & 179 \\
Fe-0.05 PILC & 190 & 19 & 170 \\
Fe-0.15 PILC & 195 & 101 & 94 \\
Fe-0.5 PILC & 172 & 135 & 38 \\
\hline
\end{tabular}




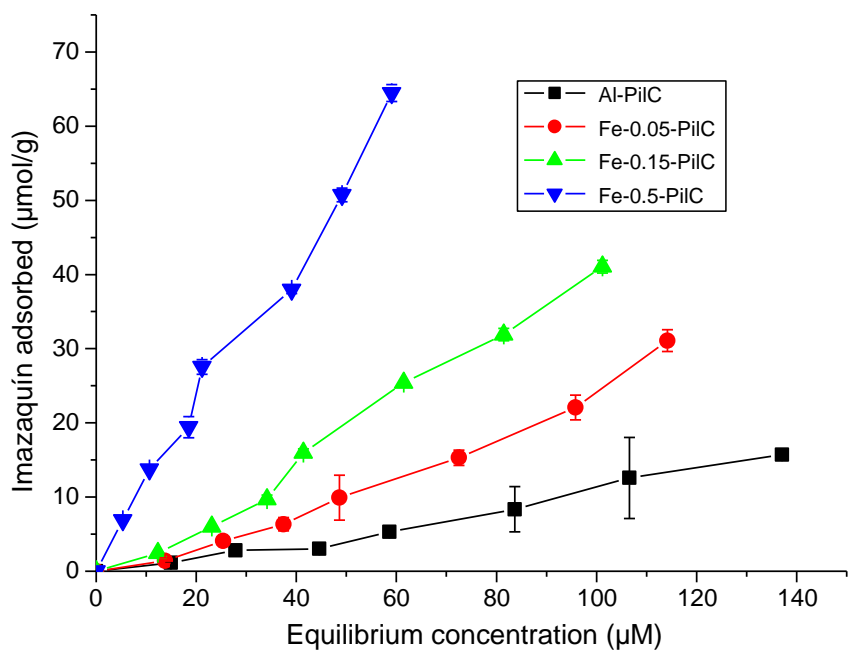

Fig. 3. Adsorption isotherms of imazaquin on PILCs.

Fe content the lowest the desorption percents. This suggests that other adsorption mechanisms may be operating on Fe PILC. To find out the mechanisms involved, IMZQ adsorption was performed on Al PILC and Fe-0.5PILC in the presence of competitive anions, whose adsorption was occurring through different mechanisms. The competitive anions were chloride, which was adsorbed as outer-sphere complex; phosphate, as inner-sphere complex; and sulfate, which was adsorbed by both mechanisms (Polubesova et al., 2000). The amount of adsorbed IMZQ decreased in the presence of all the electrolytes (Table 4). However, there were remarkable differences depending on the PILC. The reduction in the amount adsorbed in $\mathrm{Al}$ PILC was lower in the presence of sulfate relative to chloride. This implied a larger sorption of the herbicide on Al PILC by an electrostatic mechanism. On the contrary, the opposite trend was observed for Fe PILC, where the reduction in the adsorbed amounts was more prominent in the presence of sulfate vs. chloride. In both clay minerals, the large decrease in the adsorbed amounts in the presence of phosphate was due to the increase in the negative surface charge when phosphate was adsorbed; therefore, herbicide adsorption would decrease (Polubesova et al., 2002).

Carboxylic herbicide adsorption on iron and aluminum oxides is strongly dependent on the herbicide structure. Adsorption of 2,4-D occurred through coulombic interactions between the organic anion and the positively charged oxide surfaces (Clausen and Fabricius, 2001; Watson et al., 1973). Vasudevan et al. (2002) observed a preferential adsorption of the herbicide quinmerac on iron oxides such as hematite and goethite over Al oxides; however, the herbicide 2,4-D did not show any selectivity. These authors suggested that other additional mechanisms on quinmerac adsorption were operating, and rationalized the higher preference over Fe oxides on the contribution between the heterocyclic $\mathrm{N}$ and $\mathrm{Fe}$ (III) in the formation of covalent bond. The herbicides IMZQ and quinmerac have analogous chemical structures; both of them are quinoline-carboxylic acids, suggesting similar adsorption mechanisms. Marco-Brown et al. (2012) observed similar coordination of the pyridinic nitrogen of the herbicide picloram with the surface iron centers on Fe PILC.

\section{Table 3}

Percentages of imazaquin desorbed as a function of the concentration used. ${ }^{a}$

\begin{tabular}{lllll}
\hline IMZQ added, $\mu \mathrm{M}$ & Al PILC & Fe-0.05 PILC & Fe-0.15 PILC & Fe-0.5 PILC \\
\hline 16 & $75.8 \pm 6.1 \%$ & $80.7 \pm 5.4 \%$ & $83.3 \pm 9.0 \%$ & $52.3 \pm 1.0 \%$ \\
64 & $73.0 \pm 5.7 \%$ & $80.5 \pm 3.2 \%$ & $66.4 \pm 2.1 \%$ & $48.6 \pm 0.1 \%$ \\
160 & $73.4 \pm 3.6 \%$ & $64.5 \pm 2.3 \%$ & $56.6 \pm 1.8 \%$ & $38.5 \pm 0.2 \%$ \\
\hline
\end{tabular}

a Clay mineral concentration was $1.6 \mathrm{~g} / \mathrm{L}$.
Table 4

Reduction percents in imazaquin adsorption on PILCs in the presence of several electrolytes. Imazaquin to anion ratio was $1: 1 .^{\mathrm{a}}$

\begin{tabular}{llll}
\hline & $\mathrm{NaCl}$ & \multicolumn{1}{c}{$\mathrm{Na}_{2} \mathrm{SO}_{4}$} & $\mathrm{Na}_{3} \mathrm{PO}_{4}$ \\
\hline Al PILC & $11.01 \pm 1.63$ & $6.18 \pm 0.57$ & $86.72 \pm 1.94$ \\
Fe-0.5 PILC & $30.42 \pm 1.84$ & $74.51 \pm 1.37$ & $92.58 \pm 3.5$ \\
\hline
\end{tabular}

a The added amount of herbicide was $160 \mu \mathrm{M}$.

The results of this study also pointed out to a preferential adsorption mechanism of IMZQ on Fe PILCs through formation of innersphere complexes. Leone et al. (2001) attributed to a ligand exchange mechanism the adsorption of imidazolinone herbicides on the iron oxide ferrihydrite. Both mechanisms can be operating on Fe PILC which permits to explain the high herbicide affinity compared to Al PILC as noticed in the high adsorption values and low desorption percents.

Evidence of the mechanisms involved in the adsorption of the herbicide on the Fe PILC was partly supported by IR spectroscopy (Fig. 4). The spectra of the herbicide showed absorption bands at 1732 and $1694 \mathrm{~cm}^{-1}$ due to carbonyl stretching vibrations of the carboxylic and ketone moieties, respectively; multiple ring vibrations arising mainly from the quinoline moiety between 1650 and $1300 \mathrm{~cm}^{-1}$ $\left(1643,1563,1487,1450,1402,1365,1315,1290 \mathrm{~cm}^{-1}\right) ; \mathrm{C}-\mathrm{H}$ in-plane bending vibrations in the $1300-1050 \mathrm{~cm}^{-1}$ range (specifically, 1268, 1209 and $1123 \mathrm{~cm}^{-1}$ ), C-H out-of-plane bending vibrations below $1000 \mathrm{~cm}^{-1}$ (at 982, 858, $799 \mathrm{~cm}^{-1}$ ) and $\mathrm{C}-\mathrm{H}$ wagging coupled with a ring vibration at $758 \mathrm{~cm}^{-1}$ (Bajpai et al., 2000; Kumru et al., 2012; Ozël et al., 2001). In the Fe PILC (Fig. 4b), the position and assignment of the main absorption bands were (Qin et al., 2010; Yuan et al., 2008): $1636 \mathrm{~cm}^{-1}$ to $\mathrm{OH}$ bending of water; $1013 \mathrm{~cm}^{-1}$ to $\mathrm{Si}-\mathrm{O}$ stretching vibration; $916 \mathrm{~cm}^{-1}$ to $\mathrm{Al}-\mathrm{Al}-\mathrm{OH}$ deformation; and 882 and $796 \mathrm{~cm}^{-1}$ to $\mathrm{Si}-\mathrm{O}$ vibrations of some quartz impurities of the raw mineral. The IR spectrum after adsorption of the herbicide (Fig. 4c) showed some features suggesting the involvement of $\mathrm{N}$-donor ligand and formation of inner-sphere complexes: i) Fe-N coordination through the quinoline moiety were reported by Özel et al. (2001) to yield upward shifts of most of the ring vibrations between 4 and $22 \mathrm{~cm}^{-1}$ as in Fig. 4c (1457, 1408, $\left.1369,1329,1297 \mathrm{~cm}^{-1}\right)$; and ii) the absence of the ring vibration bands at 1643 and $1563 \mathrm{~cm}^{-1}$ of the pristine herbicide (Fig. 4a) which are associated to protonated quinoline nitrogen (quinolinium moieties) (Pusino et al., 2003) and used as a fingerprint for determination of Brönsted acid sites in clay minerals (Corma et al., 1993), also suggested coordination of the $\mathrm{N}$ atom of the quinoline ring to Fe centers. In addition, the new absorption bands at 1250 and $1188 \mathrm{~cm}^{-1}$ were due to $\mathrm{C}-\mathrm{O}$ stretching vibrations resulting from the reaction of the carboxylic moiety with Fe oxyhydroxides, similarly to esters of inorganic alcohols. The lack of detection of the $C=0$ stretching frequency in these types of interactions is due to the fact that it can vary within very wide limits and therefore, not found at the typical carbonyl frequencies of normal saturated esters with organic alcohols (1750-1730 $\mathrm{cm}^{-1}$ ) (Bellamy, 1975). These results also point out formation of inner-sphere complexes of the herbicide through its carboxylic moiety to Fe pillars.

\subsection{Solubility diagrams of imazaquin in the presence of cyclodextrins}

Solubility diagrams of IMZQ with four CDs showed a linear increase in the herbicide solubility when increasing $C D$ concentration (Fig. 5). These curves were indicating formation in solution of complexes without a defined solubility limit, which corresponded to $A_{L}$ type according to Higuchi and Connors classification (Higuchi and Connors, 1965). $A_{L}$ type indicates formation of $1: 1$ inclusion complexes between $\mathrm{CD}$ and the guest molecule. The conditional formation 
a)
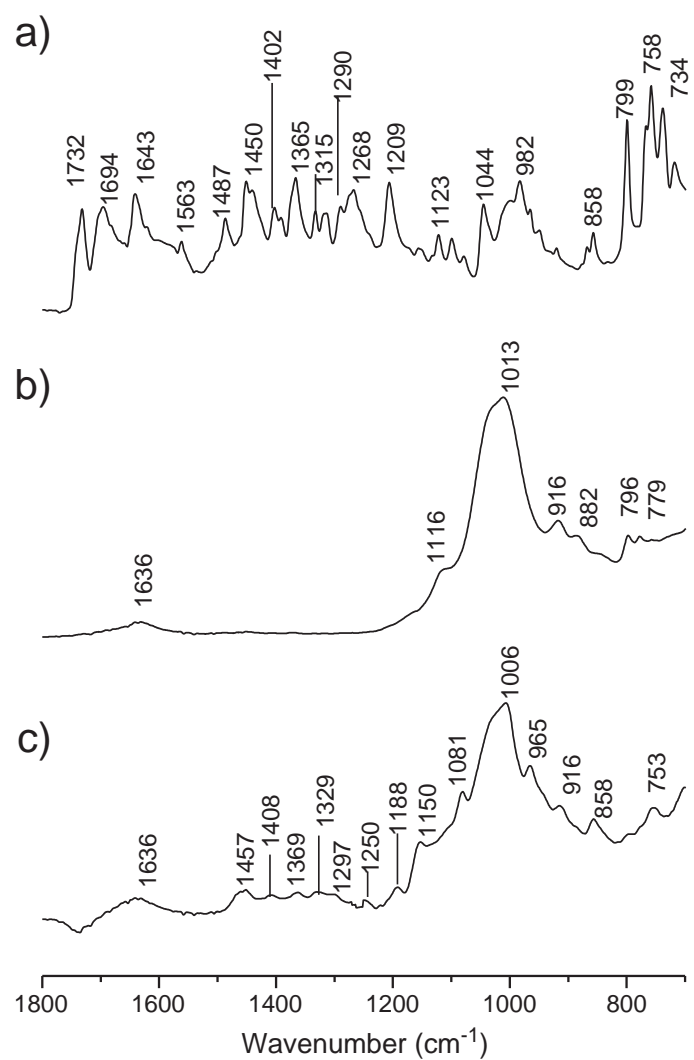

Fig. 4. FTIR spectra of (a) IMZQ (b) Fe-0.5-PILC and (c) after IMZQ sorption on Fe-0.5-PILC.

constants of the complexes were calculated as well as the maximal increment in the herbicide solubility (Table 5).

The values of the apparent stability constants $(\mathrm{Kc})$ for $\beta-C D$ and its derivatives were much larger than that of $\alpha-C D$. The low value for this $\mathrm{CD}$ can be due to the more reduced dimensions of its cavity, which would hinder the entrance of the herbicide; therefore the interaction mode will be different when using $\beta-C D$ and derivatives which present a more optimal accommodation between the hydrophobic cavity and the non-polar moieties of the herbicide.

The highest complexation constant as well as the maximal increment in IMZQ solubility occurred with HPß (up to 8-fold for $0.1 \mathrm{M}$ concentration). A similar value of constant was observed for $\beta-C D$

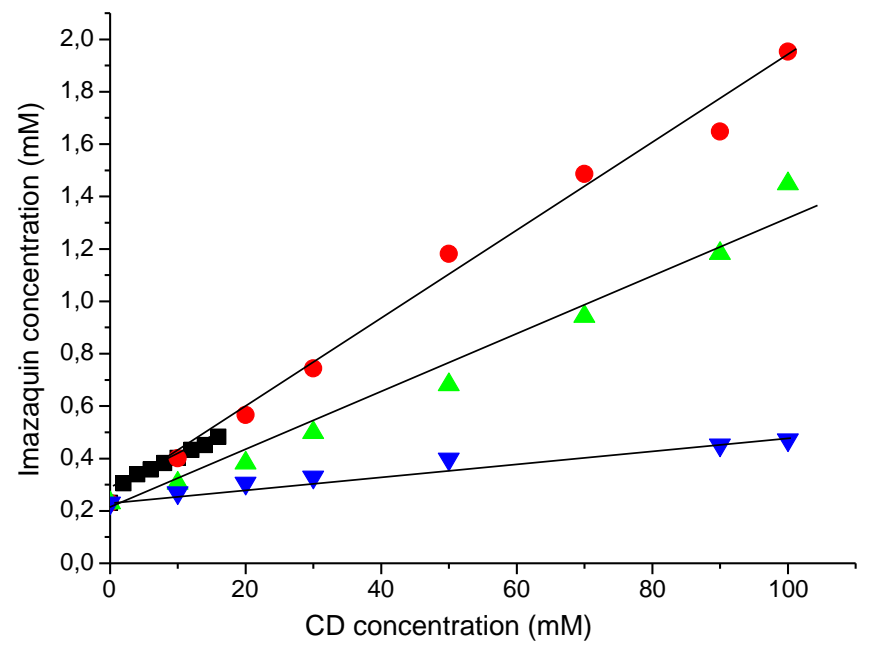

Fig. 5. Phase solubility diagrams of imazaquin in aqueous solutions in the presence of $\mathrm{CD}:(\boldsymbol{\nabla}) \alpha-\mathrm{CD},(\boldsymbol{\square}) \beta-\mathrm{CD},(\boldsymbol{\Lambda}) \mathrm{RAME} \beta$ and $(\bullet) \mathrm{HP} \beta$.
Table 5

Apparent stability constants $(\mathrm{Kc})$, correlation factors $\left(\mathrm{R}^{2}\right)$, and solubility increase (Se, using $0-0.016 \mathrm{M}$ for $\beta-\mathrm{CD}$ and $0-0.1 \mathrm{M}$ for the other $\mathrm{CDs}$ ) for the inclusion compounds obtained between imazaquin and the different CDs.

\begin{tabular}{lllll}
\hline & $\beta-C D$ & HP $\beta$ & RAME $\beta$ & $\alpha$-CD \\
\hline $\mathrm{K}\left(\mathrm{M}^{-1}\right)$ & $71.0 \pm 4.7$ & $85.4 \pm 2.6$ & $59.2 \pm 2.6$ & $11.5 \pm 3.4$ \\
$\mathrm{Se}$ & 2.0 & 8.5 & 6.3 & 2.0 \\
$\mathrm{R}^{2}$ & 0.960 & 0.990 & 0.981 & 0.966 \\
\hline
\end{tabular}

but the enhanced solubility of the herbicide was lower due to its lower solubility. The enhanced solubility of the herbicide was also remarkable with RAMEß, with solubility increments up to 6-fold for a $0.1 \mathrm{M}$ concentration and high complexation constant.

\subsection{Study of imazaquin-cyclodextrin inclusion complexes}

${ }^{1} \mathrm{H}-\mathrm{NMR}$ spectroscopy is a useful and powerful tool which permits the characterization of complexes in solution by monitoring the chemical shifts of CD-protons and those of the guest molecule. Table 6 shows the chemical shifts for the herbicide and for its inclusion complex with RAMEß. The shifts for CD protons were not possible to monitor due to the high free $C D$ concentration relative to the fraction forming inclusion complexes. Consequently, the changes were only followed in the herbicide spectra whose peaks did not overlap with those of the $C D$.

Studies on inclusion complexes of $\beta-C D$ and derivatives showed shifts to low fields of the guest molecule protons which are interacting within the CD cavity (Goyenechea et al., 2001; Lezcano et al., 2003; Pérez-Martínez et al., 2000). In Table 6, the highest shift was obtained for $\mathrm{H}-4$. High shifts were also observed for $\mathrm{H}-6$ and $\mathrm{H}-7$. These features indicated interaction of the herbicide via the quinolinic ring with the $\mathrm{CD}$. However, the shifts of these aromatic protons were occurring at high field instead. Masson et al. (1998) observed a similar effect on chlorambucil inclusion with $\beta-C D$, which was explained on the basis of the opposite effect produced by strong hydrogen bonding involving $\mathrm{N}$ electro pair with the $\mathrm{CD}$. These data pointed out that the quinolinic moiety of the herbicide is partially trapped within the CD cavity, with the quinolinic $\mathrm{N}$ atom outside of the cavity and forming strong H-bonding with polarized water molecules or hydroxyl groups of the $\mathrm{CD}$. The small chemical shifts of protons located in the imidazolinone ring and its substituent groups indicate that this ring was staying outside the cavity. This interaction was tried to find out which CD protons were interacting with $\mathrm{H}-4$ by performing NOE experiments. However, the results were unsuccessful due to the high amount of noncomplexed CDs. Similar observations were obtained for the other CDs.

\subsection{Adsorption of imazaquin in the presence of cyclodextrins}

In Fig. 3, adsorption of IMZQ was highest on Fe-0.5 PILC. Its adsorption was linear and limited by the solubility of the herbicide; therefore, this PILC was selected to increase IMZQ adsorption in the

Table 6

Chemical shifts of free imazaquin and RAMEß: IMZQ complexes from ${ }^{1} \mathrm{H}-\mathrm{NMR}$ measurements (500 MHz, DMSO).

\begin{tabular}{lllll}
\hline Proton & Signal & $\delta$ (IMZQ) & $\delta$ (RAMEß-IMZQ) & $\Delta \delta$ \\
\hline $\mathrm{H}-4$ & Singlet & 8.927 & 8.845 & -0.082 \\
$\mathrm{H}-6$ & Double doublet & 8.227 & 8.187 & -0.040 \\
$\mathrm{H}-7$ & Multiplet & 7.972 & 7.927 & -0.045 \\
$\mathrm{H}-8$ & Multiplet & 7.803 & 7.772 & -0.031 \\
$\mathrm{H}-9$ & Double doublet & 8.169 & 8.144 & -0.025 \\
$\mathrm{CH}$ & Singlet & 1.275 & 1.254 & -0.021 \\
$\mathrm{CH}\left(\mathrm{CH}_{3}\right)_{2}$ & Doublet & 1.021 & 1.015 & -0.006 \\
$\mathrm{CH}\left(\overline{\mathrm{CH}_{3}}\right)_{2}$ & Doublet & 0.863 & 0.865 & +0.002 \\
$\mathrm{CH}\left(\overline{\mathrm{CH}_{3}}\right)_{2}$ & Multiplet & 1.960 & 1.949 & -0.011 \\
\hline
\end{tabular}


presence of CD. Adsorption of the herbicide from CD-IMZQ would promote the amount of adsorbed herbicide by enhancement of IMZQ solubility. The CD would be only acting as a solubilizing agent to increase the active ingredient content in the PILC-based formulations. The CDs used were only RAMEß and HPß because their herbicide solubility increments are the largest (Table 5).

Adsorption of the herbicide from CD-IMZQ complexes increased largely the amount of herbicide adsorbed compared to its adsorption in the absence of $\mathrm{CD}$ (Fig. 6). Herbicide adsorption increased by $42 \%$ in the presence of RAME $\beta$. Smaller increments were obtained for HPß, which is in good agreement with its higher complexation constant. The $C D$ in solution is competing with the sorption sites on the Fe PILC for IMZQ, impeding a larger adsorption. Adsorption of both CD on Fe PILC was determined to be negligible.

\subsection{Release studies}

Fig. 7 shows the elution curves of the commercial formulation Scepter as well as those of Fe-0.5 PILC prepared in the presence of CD. After 14 irrigations, the amount released from the total applied was $87.8 \pm 3.1 \%$ for the commercial formulation. The high elution obtained in this sandy soil with the commercial formulation agrees with the study by Undabeytia et al. (2004) who determined that adsorption of the herbicide on this soil mainly occurred through the organic matter, from which desorbed easily. After 14 irrigations, the total amounts released from the total applied were $40.2 \pm 6.7$ and $47.4 \pm 4.8 \%$ for those prepared, respectively, with RAME $\beta$ and HP $\beta$, amounting to a significant reduction in release of 54 and $46 \%$, respectively, compared to the commercial formulation.

\section{Conclusions}

Fe PILCs were synthesized for the design of slow release formulations of the herbicide IMZQ. The approach used was the high affinity of this herbicide observed for iron oxide surfaces; therefore, an enhanced adsorption of the herbicide on iron-based clay minerals which paralleled a slow release could be achieved. Fe PILCs were synthesized and characterized. XRD and porosity measurements were in agreement with previous studies indicating a mesoporous structure formed by coaggregation of iron oxide clusters with clay mineral delaminated layers. Unless tight binding mechanisms are operating, a large pore will facilitate the interaction of the herbicide with iron nodules and also IMZQ desorption from the Fe PILCs. Competitive adsorption of anions showed that IMZQ was adsorbed mainly by inner-sphere complexation; however, other

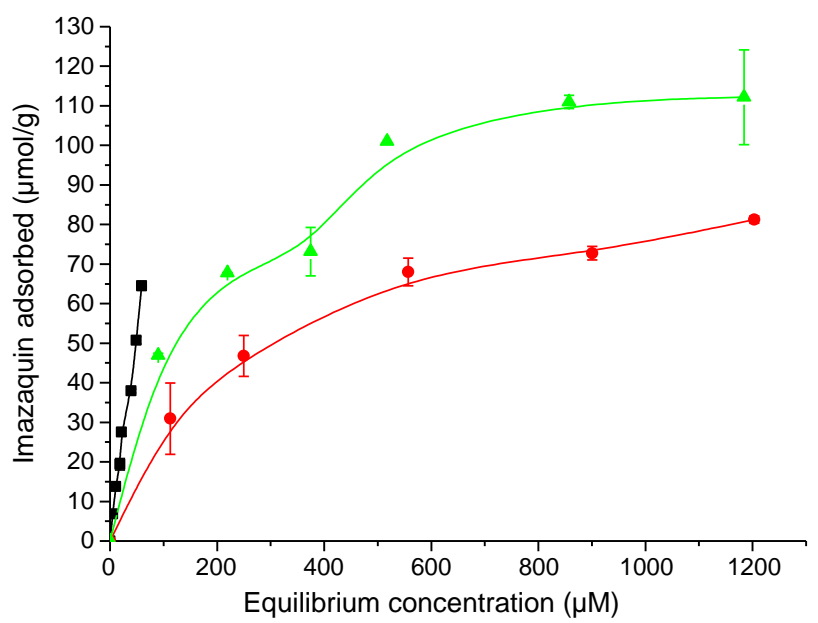

Fig. 6. Adsorption isotherms of imazaquin on Fe-0.5-PILC in the absence ( $\boldsymbol{\square}$ ) and presence of RAMEß ( $\mathbf{\Delta})$ and $\mathrm{HP} \beta(\bullet)$.

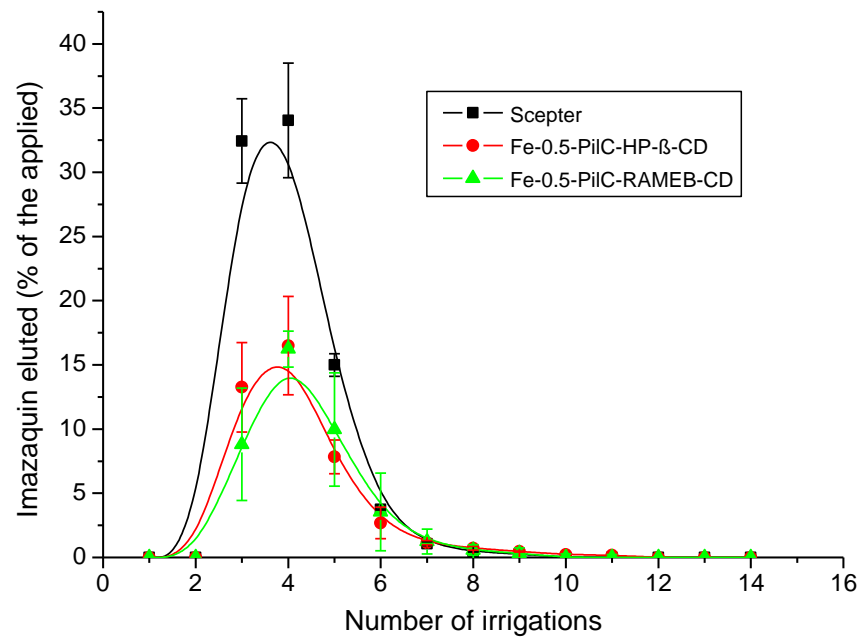

Fig. 7. Herbicide release from the commercial and Fe PILC formulations.

mechanisms may be acting. Inner-sphere complexation was also supported by IR spectroscopy.

The increase in the loading of herbicide on clay minerals for preparation of formulations is usually hindered by the herbicide solubility. This is overcome by the use of solubilizing agents, usually surfactants. However, the use of CDs, which are non-toxic, biodegradable chemicals, is a good alternative. IMZQ solubility was greatly enhanced in the presence of $C D$, by the formation of inclusion complexes. The use of these complexes increased the amount of IMZQ adsorbed on the clay mineral up to $42 \%$. Release of the herbicide in sandy soil from formulations prepared from CD-IMZQ complexes was retarded by $1 / 2$-fold compared to the commercial formulation Scepter.

\section{Acknowledgments}

This research was supported by the MEC Project CTM2009-07425 and the Junta de Andalucía Project P09-RNM4581. Both projects received funding by the European Social Fund. The authors acknowledge the CITIUS service from the University of Seville for the NMR facilities.

\section{References}

Ahrens, H.W., 1994. Herbicide Handbook, 7 ed. Weed Science Society of America, Champaign, IL.

Aouad, A., Anastácio, A.S., Bergaya, F., Stucki, J.W., 2010. A Mössbauer spectroscopy study of aluminum- and iron-pillared clay minerals. Clays and Clay Minerals 58, 164-173.

Bajpai, U.C., Gupta, D.C., Singh, R.B., Saxena, M., Saxena, A.K., 2000. Fourier transform infrared spectra and normal mode analysis of 1-(3-methyl phenyl piperazin-1-yl)-2(quinolin-2-yl) ethane (centhaquin): a potent centrally acting anti-hypertensive agent. Journal of Molecular Structure 516, 15-21.

Bakas, T., Moukarika, A., Papaefthymiou, V., Ladavos, A., 1994. Redox treatment of an Fe/Al pillared montmorillonite. A Mössbauer study. Clays and Clay Minerals 42, 634-642.

Bandosz, T.J., Cheng, K., 1997. Changes in acidity of Fe-pillared/delaminated smectites on heat treatment. Journal of Colloid and Interface Science 191, 456-463.

Bellamy, L.J., 1975. The Infra-Red Spectra of Complex Molecules. Chapman \& Hall Ltd., London, GB.

Bergaya, F., Aouad, A., Mandalia, T., 2006. Pillared clays and clay minerals. In: Bergaya, F., Theng, B.K.G., Lagaly, G. (Eds.), Handbook of Clay Science, pp. 393-421 (Chapter 7.5).

Bikiaris, D.N., 2011. Solid dispersions, part I: recent evolutions and future opportunities in manufacturing methods for dissolution rate enhancement of poorly watersoluble drugs. Expert Opinion on Drug Delivery 8, 1501-1519.

Bojemueller, E., Nennemann, A., Lagaly, G., 2001. Enhanced pesticide adsorption by thermally modified bentonites. Applied Clay Science 18, 277-284.

Bradley, S.M., Kydd, R.A., 1993. $\mathrm{Ga}_{13}, \mathrm{Al}_{13}, \mathrm{GaAl}_{12}$, and chromium-pillared montmorillonitesacidity and reactivity for cumene conversion. Journal of Catalysis 141, 239-249.

Cañizares, P., Valverde, J.L., SunKou, M.R., Molina, C.B., 1999. Synthesis and characterization of PILCs with single and mixed oxide pillars prepared from two different bentonites. A comparative study. Microporous and Mesoporous Materials 29, 267-281. 
Cheknane, B., Baudu, M., Basly, J.P., Bouras, O., 2010. Adsorption of basic dyes in single and mixture systems on granular inorganic-organic pillared clays. Environmental Technology 31, 815-822.

Clausen, L., Fabricius, I., 2001. Atrazine, isoproturon, mecocrop, 2,4-D, and bentazone adsorption onto iron oxides. Journal of Environmental Quality 30, 858-869.

Clinard, C., Mandalia, T., Tchoubar, D., Bergaya, F., 2003. HRTEM image filtration: nanostructural analysis of a pillared clay. Clays and Clay Minerals 51, 421-429.

Corma, A., Fornés, V., Rey, F., 1993. Quinoline as a probe molecule for determination of external Brönsted and Lewis acidity in zeolites. Zeolites 13, 56-59.

Erre, L.S., Garribba, E., Micera, G., Sardone, N., 1998. Metal complexes of imazapyr, a herbicide provided with efficient metal-chelating ability: crystal structure of the cobalt (II) and manganese (II) complexes. Inorganica Chimica Acta 272, 68-73.

Fenyvesi, E., Balogh, K., Olah, E., Batai, B., Varga, E., Molnar, M., Gruiz, K., 2011. Cyclodextrins for remediation of soils contaminated with chlorinated organics. Journal of Inclusion Phenomena and Macrocyclic Chemistry 70, 291-297.

Fernández-Urrusono, R., Ginés, J.M., Morillo, E., 2000. Development of controlled release formulations of alachlor in ethylcellulose. Journal of Microencapsulation 17, 331-342.

Finizio, A., Azimonti, G., Villa, S., 2011. Occurrence of pesticides in surface water bodies: a critical analysis of the Italian national pesticide survey. Journal of Environmental Monitoring 13, 49-57.

Gennari, M., Negre, M., Vindrola, D., 1998. Adsorption of the herbicides imazapyr, imazethapyr and imazaquin on soils and humic acids. Journal of Environmental Science and Health B33, 547-567.

Gerstl, Z., Nasser, A., Mingelgrin, U., 1998. Controlled release of pesticides into soils from clay-polymer formulations. Journal of Agricultural and Food Chemistry 46, 3797-3802.

Goyenechea, N., Sánchez, M., Velaz, I., Martín, C., Martínez-Oharriz, M.C., GonzálezGaitano, G., 2001. Inclusion complexes of nabumetone with beta-cyclodextrins: thermodynamics and molecular modelling studies. Influence of sodium perchlorate. Luminescence $16,117-127$.

Heylen, I., Vansant, E.F., 1997. The difference in adsorption capacity between Fe-PILCs and modified Fe-BuA- and Fe-Zr-PILCs. Microporous Materials 10, 41-50.

Higuchi, T., Connors, K.A., 1965. Phase-solubility techniques. Advances in Analytical Chemistry and Instrumentation 4, 117-212.

Kumru, M., Küçük, V., Bardakçi, T., 2012. Theoretical and experimental studies on the vibrational spectra of 3-quinolincarboxaldehyde. Spectrochimica Acta Part A 90, 28-34.

Leone, P., Gennari, M., Negre, M., Boero, V., 2001. Role of ferrihydrite in adsorption of three imidazolinone herbicides. Journal of Agricultural and Food Chemistry 49, $1315-1320$.

Lezcano, M., Novo, M., Al-Soufi, W., Rodríguez-Núñez, E., Tato, J.V., 2003. Complexation of several fungicides with beta-cyclodextrin: determination of the association constants and isolation of the solid complexes. Journal of Agricultural and Food Chemistry 51, 5036-5040.

Li, J.F., Jiang, M., Wu, H., Li, Y.M., 2009. Addition of modified bentonites in polymer gel formulation of 2,4-D for its controlled release in water and soil. Journal of Agricultural and Food Chemistry 57, 2868-2874.

Mandalia, T., Crespin, D., Messad, D., Bergaya, F., 1998. Large interlayer repeat distances observed for montmorillonites treated by mixed $\mathrm{Al}-\mathrm{Fe}$ and $\mathrm{Fe}$ pillaring solutions. Chemical Communications 19, 2111-2112.

Maqueda, C., Villaverde, J., Sopeña, F., Undabeytia, T., Morillo, E., 2008. Novel system for reducing leaching of the herbicide metribuzin using clay-gel-based formulations. Journal of Agricultural and Food Chemistry 56, 11941-11946.

Maqueda, C., Villaverde, J., Sopeña, F., Undabeytia, T., Morillo, E., 2009. Effects of soil characteristics on metribuzin dissipation using clay-gel-based formulations. Journal of Agricultural and Food Chemistry 57, 3273-3278.

Marco-Brown, J.L., Martín Barbosa-Lema, C., Torres Sánchez, R.M., Mercader, R.C., dos Santos Afonso, M., 2012. Adsorption of picloram herbicide on iron oxide pillared montmorillonite. Applied Clay Science 58, 25-33.

Masson, M., Loftsson, T., Jóndóttir, S., Fridiksdóttir, H., 1998. Stabilisation of ionic drugs through complexation with non-ionic and ionic cyclodextrins. International Journal of Pharmaceutics 164, 45-55.

Metcalfe, C.D., Beddows, P.A., Bouchot, G.G., Metcalfe, T.L., Li, H.X., Van Lavieren, H., 2011. Contaminants in the coastal karst aquifer system along the Caribbean coast of the Yucatan Peninsula, Mexico. Environmental Pollution 159, 991-997.

Mishael, Y.G., Undabeytia, T., Rabinovitz, O., Rubin, B., Nir, S., 2003. Sulfosulfuron incorporated in micelles adsorbed on montmorillonite for slow release formulations. Journal of Agricultural and Food Chemistry 51, 2253-2259.

Mishra, T., Parika, K.M., Rao, S.B., 1996. Transition metal oxide pillared clay: 1. A comparative study of textural and acidic properties of Fe(III) pillared montmorillonite and pillared acid activated montmorillonite. Journal of Colloid and Interface Science $183,176-183$.

Nennemann, A., Kulbach, S., Lagaly, G., 2001a. Entrapping pesticides by coagulation smectites. Applied Clay Science 18, 285-298.

Nennemann, A., Mishael, Y.G., Nir, S., Rubin, B., Polubesova, T., Bergaya, F., van Damme, H., Lagaly, G., 2001b. Clay-based formulations of metolachlor with reduced leaching. Applied Clay Science 18, 265-275.
.M., 1984. Interactions of polycations of aluminium and iron with clays. Clays and Clay Minerals 32, 49-57.

Özel, A.E., Büyükmurat, Y., Akyüz, S., 2001. Infrared-spectra and normal-coordinate analysis of quinoline and quinoline complexes. Journal of Molecular Structure 565-566, 455-462.

Pérez-Martínez, J.I., Ginés, J.M., Morillo, E., Moyano, J.R., 2000. ${ }^{1} \mathrm{H}$-nuclear magnetic resonance and phase solubility studies of the stoichiometries in 2,4-D: alpha- and beta-cyclodextrins inclusion complexes. Journal of Inclusion Phenomena and Macrocyclic Chemistry 37, 171-178.

Pinnavaia, T.J., Raythatha, R.H., Tzou, M.S., Landau, S.D., 1983. Pillared and delaminated clay catalysts. Abstracts of Papers of the American Chemical Society 186 (59-INDE).

Polubesova, T., Undabeytia, T., Nir, S., Chertkova, L., Van Damme, H., Annabi-Bergaya, F. 2000. Adsorption of sulfometuron and other anions on pillared clay. Journal of Environmental Quality 29, 948-954.

Polubesova, T., Nir, S., Gerstl, Z., Borisover, M., Rubin, B., 2002. Imazaquin adsorbed on pillared clay and crystal violet-montmorillonite complexes for reduced leaching in soil. Journal of Environmental Quality 31, 1657-1664.

Pusino, A., Gelsomino, A., Fiori, A., Gessa, C., 2003. Adsorption of two quinolinecarboxylic acid herbicides on homoionic montmorillonites. Clays and Clay Minerals 51, 143-149.

Qin, Z., Yuan, P., Zhu, J., He, H., Liu, D., Yang, S., 2010. Influences of thermal pretreatment temperature and solvent on the organosilane modification of Al13intercalated/Al-pillared montmorillonite. Applied Clay Science 50, 546-553.

Regitano, J.B., Bischoff, M., Lee, L.S., Reichert, J.M., Turco, R.F., 1997. Retention of imazaquin in soil. Environmental Toxicology and Chemistry 16, 397-404.

Regitano, J.B., Da Rocha, W.S.D., Alleoni, L.R.F., 2005. Soil pH on mobility of imazaquin in oxisols with positive balance of charges. Journal of Agricultural and Food Chemistry 53, 4096-4102.

Schutz, A., Plee, D., Borg, F., Jacobs, P., Poncelet, G., Fripiat, J.J., Van Olphen y, H., 1987. Acidity and catalytic properties of pillared montmorillonite and beidellite. In: Schultz, L.C., Mumpton, F.A. (Eds.), Proceedings of the International Clay Conference, Denver, 1985. The Clay Minerals Society, Bloomington, Indiana, pp. 305-310.

Sopeña, F., Cabrera, A., Maqueda, C., Morillo, E., 2005. Controlled release of the herbicide norflurazon into water from ethylcellulose formulations. Journal of Agricultural and Food Chemistry 53, 3540-3547.

Szejtli, J., 1998. Introduction and general overview of cyclodextrin chemistry. Chemical Reviews 98, 1743-1753.

Takeuchi, T., Miwa, T., 1999. Indirect fluorimetric detection of cyclodextrins via postcolumn mixing with 2-p-toluidinyl-6-naphthalenesulfonate in liquid chromatography. Journal of High Resolution Chromatography 22, 609-612.

Undabeytia, T., Nir, S., Rubin, B., 2000. Organo-clay formulations of the hydrophobic herbicide norflurazon yield reduced leaching. Journal of Agricultural and Food Chemistry 48, 4767-4773.

Undabeytia, T., Mishael, Y.G., Nir, S., Papahadjopoulos-Sternberg, B., Rubin, B., Morillo, E., Maqueda, C., 2003. A novel system for reducing leaching from formulations of anionic herbicides: clay-liposomes. Environmental Science and Technology 37, 4475-4480.

Undabeytia, T., Sánchez-Verdejo, T., Morillo, E., Maqueda, C., 2004. Effect of organic amendments on the retention and mobility of imazaquin in soils. Journal of Agricultural and Food Chemistry 52, 4493-4500.

Undabeytia, T., Nir, S., Sánchez-Verdejo, T., Villaverde, J., Maqueda, C., Morillo, E., 2008. A clay-vesicle system for water purification from organic pollutants. Water Research 42, 1211-1219.

Undabeytia, T., Sopeña, F., Sánchez-Verdejo, T., Villaverde, J., Nir, S., Morillo, E., Maqueda, C., 2010. Performance of slow-release formulations of alachlor. Soil Science Society of America Journal 74, 898-905.

Undabeytia, T., Recio, E., Maqueda, C., Sánchez-Verdejo, T., Balek, V., 2012. Slow release formulations of diuron based on clay-phosphatidylcholine complexes. Applied Clay Science 55, 53-61.

Vasudevan, D., Cooper, D.M., Van Exem, O.L., 2002. Sorption-desorption of ionogenic compounds at the mineral water interface: study of metal oxide-rich soils and pure phase minerals. Environmental Science and Technology 36, 501-511.

Villaverde, J., Pérez-Martínez, J.I., Maqueda, C., Ginés, J.M., Morillo, E., 2005. Inclusion complexes of $\alpha$ - and $\gamma$-cyclodextrins and the herbicide noflurazon: I. Preparation and characterization. II. Enhanced solubilisation and removal from soils. Chemosphere 60, 656-664.

Watson, J.R., Posner, A.M., Quirk, J.P., 1973. Adsorption of the herbicide 2,4-D on goethite. Journal of Soil Science 24, 503-511.

Yuan, P., Annabi-Bergaya, F., Tao, Qj, Fan, M., Liu, Z., Zhu, J., He, H., 2008. A combined study by XRD, FTIR, TG and HRTEM on the structure of delaminated Feintercalated/pillared clay. Journal of Colloid and Interface Science 324, 142-149.

Zhenlan, Q., Heng, Y., Bin, Z., Wanguo, H., 2009. Synthesis and release behaviour of bactericides intercalated $\mathrm{Mg}-\mathrm{Al}$ layered double hydroxides. Colloids and Surfaces $\mathrm{A}$ 348, 164-169.

Zubkov, S.A., Kustov, L.M., Kazansky, V.B., Fetter, G., Tichit, D., Figueras, F., 1994. Study of the nature of acid sites of montmorillonites pillared with aluminium and oligosilsesquioxane complex cations. 1. Brönsted acidity. Clays and Clay Minerals 42, 421-427. 